\title{
ENHANCED DEGRADATION OF METALAXYL IN GLEY HUMIC AND DARK RED LATOSOL ${ }^{(1)}$
}

\author{
S. PAPINI ${ }^{(2)} \&$ M. M. ANDRÉA(3)
}

\begin{abstract}
SUMMARY
Enhanced degradation of the fungicide metalaxyl was investigated in two soils: a gley humic (GH) and a Dark Red Latosol (LE), collected at sites never exposed to the fungicide. The soil samples were treated with successive applications of metalaxyl as a commercial formulation and ${ }^{14} \mathrm{C}$-metalaxyl in laboratory. Metalaxyl biodegradation was analyzed during 63 days by means of radiometric techniques to verify biomineralization and degradation product formation from the applied ${ }^{14} \mathrm{C}$-metalaxyl. Although biomineralization (maximum of $\mathbf{1 4}$ and $8 \%$ in the GH and LE soils, respectively), and partial degradation (about 32 and 48\%, respectively) were detected in both soils, enhanced degradation was verified only in the GH soil. Results proved that metalaxyl behaves differently in soils.
\end{abstract}

Index terms: degradation, fungicide, biomineralization.

\section{RESUMO: DEGRADAÇÃO ACELERADA DO METALAXIL EM SOLOS GLEI HÚMICO E LATOSSOLO VERMELHO-ESCURO}

A degradação acel erada do fungicida metal axil foi pesquisada em dois tipos de sol os: Gle Húmico (GH) eL atossol o Vermel ho-E scuro (LE), coletados em regiões nunca antes expostas a este produto. As amostras dos sol os foram tratadas em laboratóri com apl icações sucessi vas de metalaxil em formulação comercial e ${ }^{14} \mathrm{C}$-metalaxil. A biodegradação do metalaxil foi analisada durante 63 dias, utilizando-se técnicas radiométricas de verificação de bi omineral ização eprodutos de degradação provenientes do ${ }^{14} \mathrm{C}$-metalaxil aplicado. Embora a biomineral ização (máximo de 14 e $8 \%$ nos sol os GH eLE, respectivamente) ea degradação parcial (aproximadamente 32 e $48 \%$, respecti vamente) tenham si do detectadas em ambos os sol os, o fenômeno de degradação acelerada ocorreu apenas no solo GH. Os resultados provaram que o comportamento do metalaxil mostrou-se diferente conforme o ti po de solo.

Termos deindexação: degradação, fungicida, biomineralização.

(1) Parte da Tese de Mestrado do primeiro autor apresentada ao Departamento de E col ogia, I nstituto de Biociências, da U niversidade de São Paulo. Recebido para publicação em abril de 1999 e aprovado em fevereiro de 2000.

(2) Bióloga do Centro de Proteção Ambiental, Laboratório de Ecologia de Agroquímicos, Caixa Postal 12.898, CEP 04010-970 São Paulo (SP). E-mail: solart@u-netsys.com.br

(3) Biól oga do I nstituto Biológico, Centro de ProteçãoAmbiental, Laboratório de E col ogia deAgroquímicos. E-mail: andrea@biol ogico.br 


\section{INTRODUCTION}

Repeated applications of pesticide in soils are sometimes required during the growth period of several crops, and as noticed by others, these applications may promote an increase of the soil microorganisms ableto utilize theapplied compound as nutrient and energy sources (Racke, 1990). The higher the amount of degraders of a group of pesticides, the faster its environmental dissipation. This process is known as enhanced degradation (Kaufman, 1974; Bailey \& Coffey, 1985; Felsot, 1989).

Metalaxyl [methylD,L,N-(2,6-dimetyphenyl)-N (2-methoxiacetyl)alaninate] is the fungicide active ingredient of a commercial preparation (Ridomil$50 \mathrm{GR}$ ) containing $50 \mathrm{~g} \mathrm{~kg}^{-1}$ of the active ingredient. It is used to control fungi of the Peronosporales order in citrus, potato and other vegetable crops. The pesticide presents systemic activity after direct application to the soil and root absorption (Cohen et al., 1979; Davidse, 1981; Davidse et al., 1981, Kerkenaar \& Sypesteijn, 1981; Zaki et al., 1981). Its behaviour and degradation were previously studied by others and the microbial activity was found to be an important pathway of fungicide degradation (Musumeci et al., 1981; Musumeci \& Ruegg, 1984; Bailey \& Coffey, 1985, Bailey \& Coffey, 1986; Musumeci \& Ruegg, 1986; Sharon \& Edgington, 1986).

Enhanced degradation of metalaxyl was demonstrated in soils in the United States of America (Bailey \& Coffey, 1986; Droby \& Coffey, 1991), but as this phenomenon had not been verified yet in Brazilian soils, this work has investigated the enhanced degradation of metalaxyl in different soils, under laboratory conditions.

\section{MATE RIAL AND METHODS}

\section{Soils}

The soil samples (Gley Humic - GH and Dark of Red Latosol - LE) were collected in São Paulo state from an area without previous history of exposure to metalaxyl. The physical-chemical characteristics of GH and LE soils are, respectively: 100 and $50 \mathrm{~g} \mathrm{~kg}^{-}$ 1 silt, 270 and $200 \mathrm{~g} \mathrm{~kg}^{-1}$ sand, 630 and $750 \mathrm{~g} \mathrm{~kg}^{-1}$ clay, 44 and $33 \mathrm{~g} \mathrm{dm}^{-3}$ organic matter, and $\mathrm{pH}$ of 4.6 and 4.7. Soil sampling and preparation followed the conventional methods (Pramer \& Bartha, 1972).

\section{Pesticide}

The commercial formulation of metalaxyl (containing $50 \mathrm{~g} \mathrm{~kg}^{-1}$ of metalaxyl and $950 \mathrm{~g} \mathrm{~kg}^{-1}$ of inerts) produced by Novartis was used for the repeated treatments of the soils. The ${ }^{14} \mathrm{C}$-metalaxyl (specific activity of $4.725 \mathrm{MBq} \mathrm{mg}^{-1}$ and $98 \%$ of radiochemical purity, al so provided by Novartis) was diluted in acetone to be used in the experiment.

\section{Soil treatments}

Triplicates of $25 \mathrm{~g}$ of each GH or LE soil samples were distributed in biometric flasks (Bartha \& Pramer, 1965) followed by the addition of water to $40 \%$ of soil maximum water holding capacity (International Organization for Standardization, 1992). Ten $\mathrm{mL} \mathrm{KOH} \mathrm{(0.4} \mathrm{mol} \mathrm{L-1)} \mathrm{solution} \mathrm{was}$ allocated into the lateral arm of each flask for bioactivity evaluation.

The GH and LE soil samples were separated into three groups. Firstly, all groups received $0.025 \mathrm{~g}$ of the commercial formulation/25 g soil and were incubated for 30 days at $28^{\circ} \mathrm{C}$, with controlled moisture and aeration conditions. After this time interval, two groups of each soil received a new application of $1 \mathrm{mg}$ commercial formulation/g soil and were again incubated as before. After another 30 day period, to a group of each soil which received two applications was given a third application of $1 \mathrm{mg}$ commercial formulation/g soil (Figure 1). Then, $16.6 \mathrm{kBq}(0.45 \mu \mathrm{Ci})$ of $14 \mathrm{C}$-metalaxyl in acetone solution was applied to all samples.

\section{Pesticide biomineralization}

The soil bioactivity was determined by biomineralization of ${ }^{14} \mathrm{C}$-metalaxyl to ${ }^{14} \mathrm{CO}_{2}$ which was collected in the $\mathrm{KOH}$ water solution after 14, 28, 42, 56 and 63 days (Droby \& Coffey, 1991). The ${ }^{14} \mathrm{CO}_{2}$ was quantified by liquid scintillation spectrometry counting (LSC) (Andréa et al., 1982).

\section{Other radioacarbon recovery}

After biomineralization studies, each soil sample was extracted with $150 \mathrm{~mL}$ ethyl acetate during three hours by mechanic shaking. The extracts were filtered and radiocarbon was quantified by LSC of $1 \mathrm{~mL}$ solvent samples (Mesquita \& Ruegg, 1984). The ${ }^{14} \mathrm{C}$-metalaxyl and ${ }^{14} \mathrm{C}$-metabol ites present in thesoil extracts were determinated by thin-layer chromatography (TLC) on silica gel-60 plates (Merck F 254) using ethyl acetate as developing system (Singh \& Trepathi, 1980). The ${ }^{14 C}$-metalaxyl and ${ }^{14} \mathrm{C}$-metabolites distribution was determined by dividing and cutting the plates in $1 \mathrm{~cm}$ zones, which had the radioactivity quantified by LSC of the segments. The radiocarbon not recovered as ${ }^{14} \mathrm{C}$ metalaxyl, ${ }^{14} \mathrm{C}$-metabolites or by biomineralization, was determined by combustion of extracted soil samples (Andréa et al., 1994).

The amounts of ${ }^{14} \mathrm{CO}_{2},{ }^{14} \mathrm{C}$-extractable and ${ }^{14} \mathrm{C}$ bound were calculated as percentage of applied radiocarbon, and the results wereanalyzed by MannWhitney's U-test.

\section{RESULTS AND DISCUSSION}

The ${ }^{14} \mathrm{CO}_{2}$ production increased with the number of the commercial formulation applications in the 


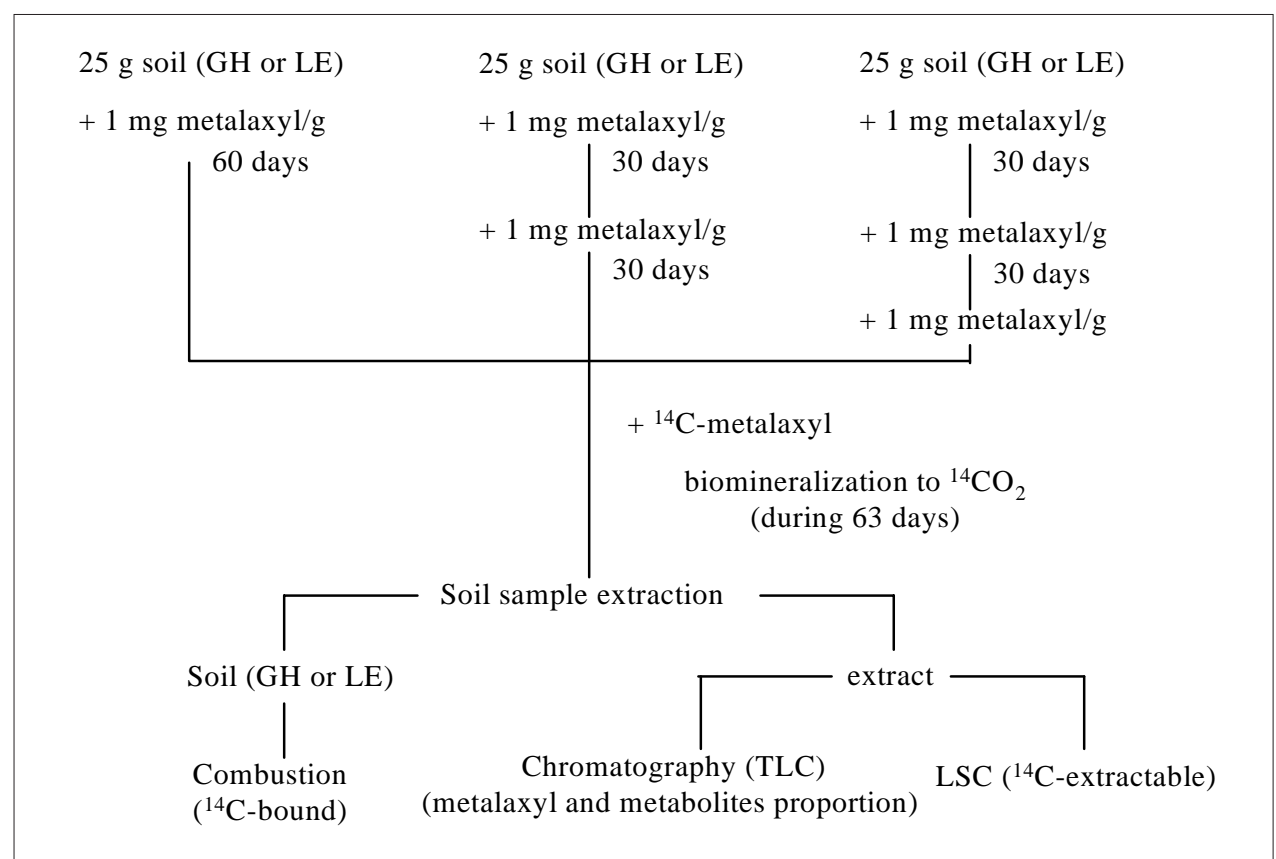

Figure 1. Diagram of the study on the behaviour of metalaxyl in a commercial formulation after one, two and three applications in Gley Humic (GH) and Dark Red Latosol (LE).

GH soil samples. Soil samples $(\mathrm{GH})$ with three applications had higher ${ }^{14} \mathrm{CO}_{2}$ production in relation to two applications, which was higher than with one fungicide application (Figure 2). The progressive increase of ${ }^{14} \mathrm{CO}_{2}$ production related to increasing numbers of treatments suggests that the successive application of the commercial formulation stimulated or selected the growth of microorganisms able to utilize and to degrade the fungicide. These results are in agreement with Bailey \& Coffey (1985) and Droby \& Coffey (1991), and indicate the occurrence of enhanced degradation of metalaxyl.
On the other hand, the LE soil samples with one, two or three applications of the metalaxylcommercial formulation showed similar rates of ${ }^{14} \mathrm{CO}_{2}$ production (Figure 3 ). The microbiota of this soil was probably not able to use the chemical efficiently, or the exposed time was not sufficient for the adaptation of the microorganisms. Thus, in the LE the repeated fungicide applications did not selectively increase the microorganism populations able to degrade metalaxyl.

The recovery of the radiocarbon from ${ }^{14} \mathrm{C}$ metalaxyl applied one, two or threetimes increased

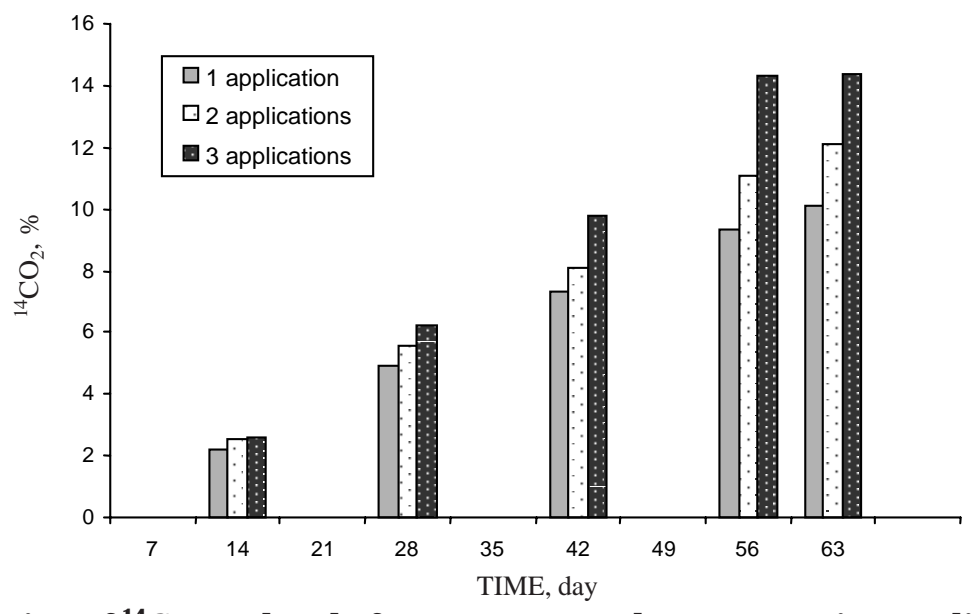

Figure 2. Mineralization of ${ }^{14} \mathrm{C}$-metalaxyl after one, two or three successive applications of a commercial formulation of metalaxyl in $\mathrm{GH}$ soil samples (cumulative values of ${ }^{14} \mathrm{CO}_{2}$ ). 


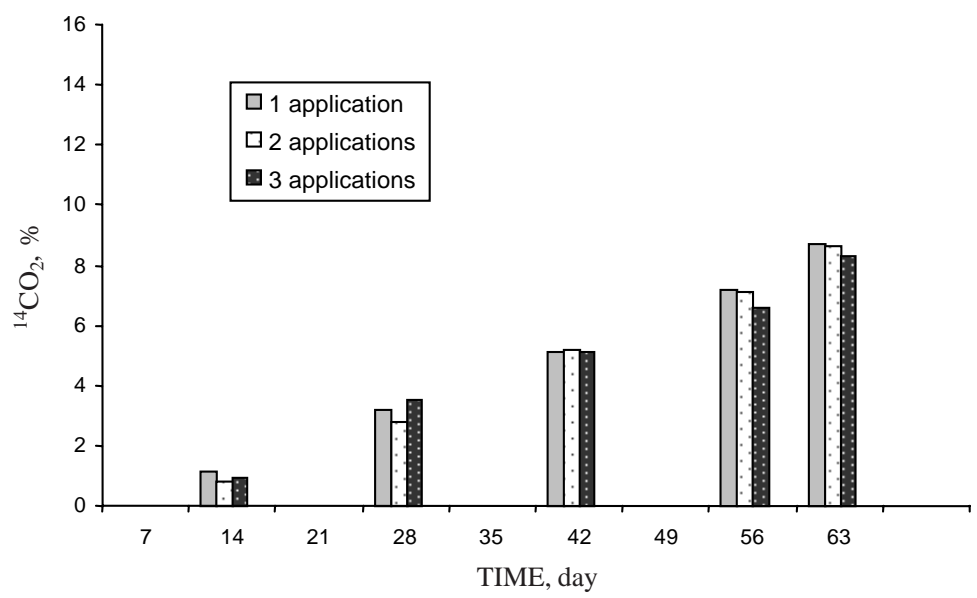

Figure 3. Mineralization of ${ }^{14} \mathrm{C}$-metalaxyl after one, two or three successive applications of a commercial formulation of metalaxyl in LE soil samples (cumulative percentage of ${ }^{14} \mathrm{CO}_{2}$ ).

as ${ }^{14} \mathrm{CO}_{2}$, decreased as ${ }^{14} \mathrm{C}$-extractable residues and increased as ${ }^{14} \mathrm{C}$-non extractable or -bound residues detected in the $\mathrm{GH}$ soil (Table 1). As pointed out by Racke (1990), the successive pesticide applications may promote the growth of part of the soil microbiota able to utilize it as nutrient or energy source, resulting in higher biomineralization as well as degradation of the compound. Thus, the successive metalaxyl applications may have favoured its biodegradation and metabolism, accounting for higher production of ${ }^{14} \mathrm{CO}_{2}$ and non-extractable residues, detected as ${ }^{14} \mathrm{C}$-bound residues. But, in the LE, although some biomineralization and metabolism were also detected, the selection of a degrader population did not happen because all the detected values were similar, independently of the number of metalaxyl applications.

These differences may be related with the different physico-chemical characteristics of the soils that may determinedifferent biol ogical characteristics. It is known that the soil organic matter content is positively related to theamount and diversity of soil microorganisms because of the higher amount of nutrients available for their growth (Kaufman, 1974; Graham-Bryce, 1981). Thus, in the GH, the higher amount of nutrients together with the presence of an indigineous microbial population ableto degrade metalaxyl, produced significant successiveincreases of metabolism, as detected by the Mann-Whitney's U-test.

On the other hand, the clay content favours the adsorption of some compounds, rendering them less available to the organisms (Walker et al., 1992). As the clay content is higher in the LE than in the GH, the clay effect may have prevailed in the LE and the applied metalaxyl might have been adsorbed by the clay particles. Consequently, it might have been protected from further metabolism.

Table 1. Radiocarbon recovery after ${ }^{14} \mathrm{C}$-metalaxyl successive applications of a commercial formulation in GH and LE soils (percentage of radiocarbon applied \pm standard deviations)

\begin{tabular}{|c|c|c|c|c|}
\hline \multirow{2}{*}{ Aplication } & \multicolumn{4}{|c|}{${ }^{14} \mathrm{C}$-recovery (percentage of total applied) } \\
\hline & ${ }^{14} \mathrm{CO}_{2}$ & ${ }^{14} \mathrm{C}$-extractable & ${ }^{14}$ C-bound & ${ }^{14} \mathrm{C}$-total \\
\hline & \multicolumn{4}{|c|}{ GH } \\
\hline 1 & $10.1 \pm 2.3$ & $40.8 \pm 7.2$ & $23.8 \pm 3.1$ & 74.8 \\
\hline 2 & $12.1 \pm 1.2$ & $49.9 \pm 5.5$ & $32.2 \pm 2.0$ & 94.2 \\
\hline \multirow[t]{2}{*}{3} & $14.4 \pm 1.9$ & $35.9 \pm 1.5$ & $37.8 \pm 3.8$ & 88.2 \\
\hline & \multicolumn{4}{|c|}{ LE } \\
\hline 1 & $8.7 \pm 0.7$ & $44.0 \pm 2.7$ & $38.8 \pm 1.3$ & 91.6 \\
\hline 2 & $8.6 \pm 1.5$ & $47.5 \pm 2.7$ & $36.2 \pm 0.2$ & 92.3 \\
\hline 3 & $8.3 \pm 1.0$ & $46.4 \pm 3.1$ & $33.8 \pm 4.4$ & 88.6 \\
\hline
\end{tabular}


The sand content is higher in the $\mathrm{GH}$ than LE, while the aeration as well as the water movement through the soil are probably higher in thefirst one, facilitating their bioactivity, because soil-air and solution are more available to the organisms (Kaufman, 1974; Nicholls, 1988).

The chromatographic analysis of soil extracts identified the degradation of ${ }^{14} \mathrm{C}$-metalaxyl in, at least, one extractable but not the ${ }^{14} \mathrm{C}$-metabolite (Rf 0.04) in both soil samples. In the GH extracts most of the ${ }^{14} \mathrm{C}$-extractable residues corresponded to metalaxyl. However, in LE the proportion between ${ }^{14} \mathrm{C}$-metalaxyl and ${ }^{14} \mathrm{C}$-metabolite (Rf 0.04) was almost the same (Table 2 ), again regardless the number of metalaxyl applications, but probably related with degradation influenced by the soil physico-chemical characteristics.

Results on biomineralization and bound residues formation proved that successive pesticide applications stimulated the total and partial degradation of the fungicide, and positively selected the microorganisms able to degrade metalaxyl only in the $\mathrm{GH}$, but not in the LE.

Table 2. Recovery of ${ }^{14} \mathrm{C}$-extractable residues by thin-layer chromatography of soils treated with ${ }^{14} \mathrm{C}$-metalaxyl

\begin{tabular}{|c|c|c|}
\hline \multirow{2}{*}{ Aplication } & \multicolumn{2}{|c|}{ Rf (percentage of the extracted) } \\
\hline & 0.46 (14C-metalaxyl) & 0.04 (14C-metabolite) \\
\hline & \multicolumn{2}{|c|}{ soil GH } \\
\hline 1 & 64.8 & 21.3 \\
\hline 2 & 54.7 & 31.7 \\
\hline \multirow[t]{2}{*}{3} & 64.3 & 11.1 \\
\hline & \multicolumn{2}{|c|}{ soil LE } \\
\hline 1 & 43.5 & 47.7 \\
\hline 2 & 51.9 & 36.7 \\
\hline 3 & 45.3 & 41.8 \\
\hline
\end{tabular}

\section{CONCLUSIONS}

1. The fungicide metalaxyl was degraded in both soils, but the metalaxyl enhanced degradation after successive applications was detected only in the GH soil.

2. Partial degradation to an extractable metabolite was independent of the number of pesticideapplications in both soils, but it was formed in lower amounts in the soil which presented enhanced degradation.

\section{LITERATURE CITED}

ANDRÉA, M.M.; LORD, K.A.; BROMILOW, R.H. \& RUEGG, E.F. Degradation of parathion by soil kept moist with and without repeated application. Environ. Pollut., 27:167-177, 1982.

ANDRÉA, M.M.; LUCHINI, L.C.; MELLO, M.H.S.H.; TOMITA, R.Y.; MESQUITA, T.B. \& MUSUMECI, M.R. Dissipation and degradation of DDT, DDE and parathion in Brazilian soils. J . Environ. Sci. Health, B29:121-132,1994.

BAILEY, A.M. \& COFFEY, M.D. Biodegradation of metalaxyl in avocado soils. Phytopathology, 75:135-137, 1985.

BAILEY, A.M. \& COFFEY, M.D. Characterization of microorganisms involved in accelerated biodegradation of metalaxyl and metalachlor in soils. Can. J. Microbiol., 32:562-569, 1986.

BARTHA, R. \& PRAMER, D. Features of a flask and method for measuring the persistence and biological effects of pesticides in soil. Soil Sci., 100:68-70, 1965.

COHEN, Y.; REVEUNI, M. \& EYAL, H. Thesystemic antifungal activity of ridomil against Phytophthora infestans on tomato plants. Dis. Control Pest. Manag., 69:645-649, 1979.

DAVIDSE, L.C. Mechanism of action of metalaxyl in Phytophthora megaspermaf sp. medicaginis. Neth. J . Plant Pathol., 87:21-25, 1981

DAVIDSE, L.C.; GERRITSMA, O.C.M. \& HOFMAN, A.E. Mode d'action du metalaxyl. Phytiatrie-Phytopharmacie, 30:235244, 1981

DROBY, S. \& COFFEY, M.D. Biodegradation process and the nature of metabolism of metalaxyl in soil. Ann. Appl. Biol., 118:543-553, 1991.

FELSOT, A.S. Enhanced biodegradation of insecticides in soils. Ann. Rev. Entomol. 34:453-476, 1989.

GRAHAM-BRYCE, I.G. The behaviour of pesticides in soil. In: GREENLAND, D.J . \& HAYES, M.H.B., eds. The chemistry of soil processes. New York, J ohn Wiley $\&$ Sons, 1981. p.621670.

INTERNATIONAL ORGANIZATION FOR STANDARDIZATIONISO (Geneva, Switzerland). ISO/DIS-11274. Geneva, 1992. 30p.

KAUFMAN, D.D. Degradation of pesticides by soil microorganisms. In: GUENZI, W.D., ed. Pesticides in soil and water. Madison, Soil Science Society of America, 1974, p.133-135.

KERKENAAR, A. \& SYPESTEIJ N, A.K. Antifungal activity of metalaxyl and furalaxyl. Pest. Biochem. Physiol., 15:71-78, 1981.

MESQUITA, T.B. \& RUEGG, E.F. Influência de agentes tensoativos na detecção da radiação beta. Ci. Cul., 36:446450, 1984

MUSUMECI, M.R.; RUEGG, E.F. \& CAMPACCI, C.A. Behaviour of ${ }^{14 C}$-metalaxyl in Brazilian soils. Turrialba, 32:496-499, 1981.

MUSUMECI, M.R. \& RUEGG, E.F. Degradação microbiana do fungicidemetalaxil no sol o. Fitopatol. Bras., 9:583-591, 1984. 
MUSUMECI, M.R. \& RUEGG, E.F. Degradação e resíduos de trifluralin e metalaxil em sol os tratados com ${ }^{14} \mathrm{C}$-triflural in e ${ }^{14} \mathrm{C}$-metalaxil em laboratório. Pesq. Agropec. Bras., 21:1023-1029, 1986.

NICHOLLS, P.H. Factors influencing entry of pesticides into soil water. Pestc. Sci., 22:123-137, 1988.

PRAMER, D. \& BARTHA, R. Preparation and processing of soil samples for biodegradation studies. Environ. Letters, 2:212224, 1972.

RACKE, K.D. Pesticides in the soil microbioal ecosystem. In: RACKE, K.D. \& COATS, J .R., eds. Enhanced biodegradation of pesticides in the environment. Washington, American Chemical Society, 1990. p.1-12. (ACS Symposium Series, 426)
SHARON, M.S. \& EDGINGTON, L.V. Mobility and dissipation of metalaxyl in tobacco soils. Can. J . Plant Sci., 66:761-771, 1986.

SINGH, U.S. \& TREPATHI, R.K. Estimation of the systemic fungicide Ridomil by thin-layer chromatography. J . Chromatog., 200:317-323, 1980.

WALKER, A.; MOON, Y.H. \& WELCH, S.J . Influence of temperature, soil moisture and soil characteristics on the persistence of alachlor. Pest. Sci., 35:109-116, 1992.

ZAKI, A.I.; ZENTMYER, G.A. \& LE BARON, H.M. Systemic translocation of ${ }^{14} \mathrm{C}$ labeled metalaxyl in tomato, avocado and Persea indica. Phytopathology, 71:509-514, 1981. 